\title{
THE CHARACTERISTICS OF AUTISM ASPERGER SYNDROME IN MARK HADDON'S NOVEL THE CURIOUS INCIDENT OF THE DOG IN THE NIGHT
}

\author{
Dhitya Anggreini, M. Manugeren \\ English Department, Faculty of Literature \\ Universitas Islam Sumatera Utara (UISU), Medan \\ e-mail: dhityaanggreni23@gmail.com
}

\begin{abstract}
This article is concerned with the protagonist of the story suffering from Asperger Syndrome. He finds difficulty in social interaction, be it appearance, language, attitude, or thinking. In addition, he has got an intelligent ability to interpret objects around him well. He has also the ability to make patterns of activities that he does every time. The whole analysis is conducted by means of qualitative research method supported by library research. The grand theory used is on autism, picturing Asperger Syndrome as an autism spectrum disorder on the high functioning end; referred to as "dash of autism". Asperger syndrome, also known as Asperger's, is a developmental disorder characterized by significant difficulties in social interaction and nonverbal communication, along with restricted and repetitive patterns of behavior and interests. The results show that the protagonist of the novel has got some significant features of Asperger Syndrome: Lacking of Social Activity, Ability of Interpreting Object, and Ability to Set Routine Patterns.
\end{abstract}

Keyword: Characteristic, Autism, Asperger Syndrome

\section{Introduction}

The Curious Incident of the Dog in the Night-Time is a 2003 mystery novel by a British writer Mark Haddon. Its title quotes the fictional detective Sherlock Holmes in Arthur Conan Doyle's 1892 short story "The Adventure of Silver Blaze". Haddon and Curious Incident won the Whitbread Book Awards for Best Novel and Book of the Year, the commonwealth Writer' prize for Best First Book, and the Guardian Children's Fiction Prize. Unusually, it was published simultaneously in separate edition for adults and children.

The Curious Incident of the Dog tells about a fifteen year old boy, named Christopher John Francis Boone who is autistic. He lives with his father, a heating contractor. He lives in Swindon, a city in England. One day he finds his neighbor's dog named Wellington killed. Since he loves it, it is important for him to find the murderer. He decides to solve the mystery. However, his father wants Christopher to stay away from a problem. Although his father forbids him to do the investigation, Christopher still keeps continuing the investigation. He also writes his investigation about the incident of the dog in a book.

One day, Christopher forgets that he has put his book on the table in the kitchen. His father finds and reads the book. He is really angry with Christopher and throws 
away the book. Christopher searches his book in his father's room. Accidentally, he finds some letters from his mother. He is really surprised to know that his mother is still alive, but his father tells him that his mother has passed away. His father also admits that he kills the dog. His confession makes Christopher frightened because for him, a murderer is a bad person and should be punished. He decides to live with his mother. $\mathrm{He}$ starts a remarkably brave experience by going to London to find his mother. Finally he finds his mother and lives with her. But one day, he has to go back to his home town to do his A math level. He goes back to his hometown with his mother because he is still afraid of his father. At the end of the story he succeeds in doing his A math level. However, no one knows that Christopher has Asperger Syndrome.

Asperger's syndrome (AS) was first described by Dr. Hans Asperger, a pediatrician in Austria in 1944. It has been more recently classified as a Pervasive Developmental Disorder. It is a neurobiological disorder generally considered as belonging to the spectrum of autism. Patients with Asperger's syndrome have intellectual capacity within the normal range with however a distinct profile of abilities apparent since early childhood. They can exhibit behaviors and marked deficiencies in social and communication skills. Asperger's syndrome is an uncommon disorder and information on prevalence is limited but it appears to be more common in males. There is no specific treatment or cure for Asperger's syndrome. All the interventions are mainly symptomatic and/or rehabilitation. (Attwood, 2003)

Asperger Syndrome is an autism spectrum disorder that is on the high functioning end of the autism spectrum; it is also referred to as "dash of autism". Incidence is more in males as compared to females. It is important to note that the characteristics of Asperger Syndrome can range from mild to severe. Asperger syndrome, also known as Asperger's, is a developmental disorder characterized by significant difficulties in social interaction and nonverbal communication, along with restricted and repetitive patterns of behavior and interests. (Frith: 1991).

Cause of Asperger Syndrome is not yet identified, although an inherited (genetic) component is believed to be involved. In special cases it may cause by pregnancy infection use of teratogens, and exposure to toxics. Some of the symptoms are: less social active, less friends, not interested in making friends, inability to express emotion, no eye contact, less facial expressions, inability to use gestures, ineffective communication, lack of relation, sensitive to external stimuli, dependent, and repetitive actions like arm waving. Children with Asperger syndrome attempts to have interaction with others, though they may have difficulty understanding conventional social rules.

\section{Literature Review}

\subsection{Autism}

Autism comes from the word "autos" which means me. In the non-scientific understanding the word can be interpreted that all children who lead themselves are called autism (Yuwono, 2009).Autism can be interpreted as a child who lives in his own world. These children tend to experience obstacles in interaction, communication, and social behavior (Haryanto, 2011:78).

Autism is not a symptom of a disease but in the form of a syndrome (collection of symptoms) where there are deviations in social development, language skills and concern for the surroundings. Autism is a condition where a child does his own way both thinking and behaving. This situation occurs from the age of 2-3 years regardless of established or less, socio-economic or adult and all ethnicities. Autism is actually not 
new and has been around for a long time, but has not been diagnosed as autistic. According to the previous story, there are often children who are considered strange, the child often shows unusual symptoms. They often talk to themselves in a language that is often not understood by their parents. If in conditions of anger they can bite, scratch, grab or attack. (Nugraheni, 2008). Azwandi (2005: 13) explains that autism has a complex developmental disorder that appears before the age of three years as a result of neurobiological disorders that have an impact on brain function. Disorders of the brain result in children with autism have obstacles both in communication, social interaction, and perila Various barriers of children with autism cause them to need special education and special services. Yuwono (2012: 26), argues that the notion of autism has been contained in the IDEA (Individuals with Disabilities Education Act) which is a developmental problem that significantly impacts on verbal communication skills, nonverbal, social interactions that generally occur before the age of three years. Supartini (2009), explains that autistic children are children who experience developmental disorders that generally occur before the age of 3 years and are complex, which have an impact on social development, communication, behavior and emotions that do not develop optimally. Hallahan \& Kauffman (2009: 433), states that autism is someone who has obstacles in aspects of social interaction, communication, repetitive behavior and stereotypes. Besides that they also experience cognitive barriers and some experience sensory perception disorders.

Autism is a disorder in the capacity for social understanding. Along with this there comes to be certain ways that the child with autism also has difficulties with language and information coming from that senses. Based on this definition, autism is defined as a disorder which makes a person have difficulty to interact and communicate with other people. A person who suffers from autism tends to withdraw his self from his social environment (Siegel, 2003).

\subsection{Asperger Syndrome}

Asperger Syndrome, also called Asperger's, is a disorder where individuals demonstrate social language difficulties and behaviors similar to those seen in children with autism. Asperger's is often referred to as "High Functioning Autism" because it may be a milder version of autistic spectrum disorder or pervasive developmental disorder. Children with Asperger's often have normal intelligence, an exceptional talent or skill, and/or an extraordinary vocabulary. Their language development appears to be typical; however, these individuals often have difficulty understanding and using nonverbal cues (gestures, body language) for social interaction. (Kirby: 2003)

One of these conditions, termed Asperger syndrome (AS) was originally described by Hans Asperger, who provided an account of a number of cases whose clinical features resembled Kanner's (1943) description of autism (e.g., problems with social interaction and communication, and circumscribed and idiosyncratic patterns of interest). However, Asperger's description differ from Kanner's in that speech is less commonly delayed, motor deficits are more common, the onset appeared to be somewhat later, and all the initial cases occur only in boys. Asperger also suggests that similar problems could be observed in family members, particularly fathers. (Ami and Fred: 2018)

People with Asperger syndrome are considered as the ones who have problem with verbal or nonverbal cues which are related to social norms. They also have difficulties to express their feelings and perceive other's feelings. "individual with 
Asperger syndrome may react inappropriately to, or fail to interpret the valence of, the context of the affective interaction, often conveying a sense of insensitivity, formality, or disregard to the other person's emotional expressions." (Ami Klin, Ph.D and Fred R. Volkmar, M.D.)

\subsection{Characteristics of Asperger Syndrome}

Some characteristics of Asperger Syndrome are: less social active, less friends, no interest in making friends, inability to express emotions, no eye contact, less facial expressions, inability to use gestures, ineffective communication, lack for relation, sensitive to external stimuli, dependent, and repetitive action like arm waving (Saraswati, 2017).

Obsessive routine (dislike transition/change), hypersensitivity (dislike certain sounds, taste, smells, and/or sight), reduced or restricted range of interest (obsesses over a particular subject), difficulty of determining proper personal space (stands/sits too close or too far from others), dislike of physical contact (prefers not to be touched), unusual tone and/or rate of speech (speaking in a high-pitched voice or very quickly/slowly), low self-esteem (having negative thoughts about oneself), difficulty of understanding figurative language (misinterpreting jokes is very literal). (Kirby, 2003)

\section{Research Method}

The research method applied is qualitative research with library study. Qualitative research method is a method used to describe fact qualitatively. (Ismawati: 2012: 7) defines that qualitative research is the research procedure resulting descriptive data of a problem in a study of research. In addition, the research is also conducted by the approach of sociology of Literature. According to the approach of sociology of literature, literary works are seen from their relationship with reality, the extent to which literary works reflect reality. The reality here is quite broad in meaning, that is, everything that is outside the literary work and which is referred to by the literary work itself. (Hidayati, 2019). The data for the research are taken from the novel The Curious Incident of the Dog in the Night-Timeand and other related sources. In a scientific research, data collection is an important element to be considered. The way of collecting the data is one important consideration. Then all the data are analyzed systematically.

\section{Results and Discussion}

The Curious Incident of the Dog in the Night-Time is a novel depicting relationship among people. This novel presents a person who is not able to overcome and maintain his behaviors and has to face it as a part of his life.

\subsection{Lacking of Social Activity}

It is obvious that somebody who suffers from Asperger Syndrome has social impairment.

"The policeman took hold of my arm and lifted me into my feet. I didn't

like him touching me like this. And this is when I hit him" (Haddon, 2003: 8)

From the above quotation, we can see that Cristopher who has Asperger Syndrome does not like a touch and he will feel threatened when someone touches him. Therefore he will do everything to protect himself. 
Christopher tends to withdraw himself from his social environment. Christopher is an introvert person. Its means that he fails to comprehend many things around him. This can be seen from some of his statements in the story.

"Talking to strangers is not something I usually do. I do not like talking to the strangers. I do not like strangers because I do not like people I have never met before they are hard understand" (Haddon, 2003: 34)

In the statement above Christopher says that he does not like talking to a stranger. He does not like new people around him. He does not like to open himself for new people who come into his life.

An autistic boy is lacking of awareness of others. It means that Christopher fails to apprehend how people around him do the interaction.

"It takes me a long time to get used to people I don't know. For example, when there is a new member of staff at school I do not talk to them for weeks and weeks. I just watch them until I know that they are safe" (Haddon, 2003: 35)

From the quotation above, Christopher says that he needs a long time to make him open himself to other people. The way he interacts to new people around him indicates that he is a person who is difficult to open himself to a new environment.

Christopher's character of being cold person indicates that he suffers from Asperger's syndrome because from time to time in the novel, he does not respond appropriately to circumstances in which he should perform empathy or sympathy. This character could be seen as incapability of reading social cues.

"Father was sitting on the sofa watching snooker on television and drinking scotch. There were tears coming out of his eyes" I asked, "Are you sad about Wellington?" He looked at me for a long time and sucked air through his nose, then he said," yes Christopher, you could say that. You could very well say that" I decided to leave him alone because when I am sad I want to left alone. So I didn't say anything else. I just went into the kitchen and made my orange squash and took it back upstairs in my room" (Haddon, 2003: 21).

The quotation above tells us that Christopher neglects his father, when he finds that his father is crying. Instead of getting surprised or showing any emotional reaction, Christopher's reaction is just flat. He only describes visually what his father has done.

\subsection{Ability of Interpreting Object}

Asperger Syndrome is usually obsessed with a particular object / subject, such as a car, airplane, or other scientific matters. They know in great detail about the things that become obsession. It can be seen in the following quotations.

"Siobhan has long blond hair and wears glasses which are made of green plastic. And Mr. Jeavons smells of soap and wears brown shoes that have approximately 60 tiny circular holes in each of them" (Haddon, 2003: 5)

The lines above describe about the way Christopher provides descriptions about his teacher, Siobhan, and the psychologist, Mr. Jeavons.

While acting as a detective to look for the murdere of Wellington, Christopher tries to ask questions about Wellington to his neighbors. And Christopher, a child with 
Asperger Syndrome, is a child who rarely communicates with strangers, but he has the ability to interpret objects in detail. We can see this from the quotation below.

"I had seen the people who lived at number 44, but I did not know what

their names were. They were black people and they were a man and a

lady with two children, a boy and a girl" (Haddon, 2003: 37)

The above quotation proves that Christopher has the ability to interpret an object. He knows the characteristics of his neighbors even though he rarely communicates with those around him. This can also be seen from the following quotation.

"I did not knock at the door of number 38, which is the house next to our house, because the people there take drugs and Father says that I should never talk to them, so I don't. And they play loud music at night and they make me scared sometimes when I see them in the street. And it is not really their house" (Haddon, 2003: 38)

According to the above quotation Christopher knows for certain about the characteristics of his neighbor who lives in house number 38 .

In addition to being smart in interpreting the characters of his neighbors, Christopher is also very clear in interpreting the sound of an object that belongs to someone else, for example the sound of a car engine owned by his father and neighbor. We can see in the following lines.

"And then I heard Father start the engine of his van. I knew it was his van because I heard it very often and it was nearby and I knew it wasn't any of the neighbors' cars because the people who take drugs have a Volkswagen camper van and Mr. Thompson, who lives at number 40, has a Vauxhall Cavalier and the people who live at number 34 have a Peugeot and they all sound different" (Haddon, 2003: 127)

The quotation above explains how Christopher interprets the differences in sound from the car engine that his father and his neighbors have.

\subsection{Ability to Set Routine Patterns}

As an Asperger Syndrome's child, Christopher is obsessed with things in the right order. If math and science are discussed from time to time, this behavior of being obsessed with things in order appear in Christopher. This obsession could be seen in how much Christopher likes timetables. Christopher applies daily schedule in details. He likes timetable because he likes to know everything.

"And at the weekend I make up my own timetable and I write it down on a piece of cardboard and I put it up on the wall. And it say things like Feed Toby or Do Math or Go to the shop to buy sweets." (Haddon, 2003: 155)

From the quotation, it is obvious that Christopher even schedules simple activities.

Making daily patterns of activity is important for Christopher, as an Asperger Syndrome, because with that he will know about things to do at a certain time, as shown below: 
And this was my timetable when I lived at home with Father and I thought that Mother was dead from a heart attack (this was the timetable for a Monday and also it is an approximation.

7:20 a.m. Getting up

7:25 a.m. Cleaning teeth and washing face

7:30 a.m. Giving Toby food and water

7:40 a.m. Having breakfast

8:00 a.m. Putting school clothes on

The information above proves that Christopher was very good at regulating the pattern of his activities. Christopher detailed the activities he would do from waking up to wanting to fall back asleep. (Haddon, 2003: 155)

The above quotation proves that Christopher, a child with Asperger Syndrome, determines the pattern of daily activities

In this novel Christopher also describes about his plan to go to London which could prove also that Christopher needs things in order.

And that I thought I would need money if I was going to London. And I would need food to eat because it was a long journey and I wouldn't know where to get food from. And then I thought I would need someone to look after Toby when I went to London because I couldn't take him with me. And then I formulated a plan. And that made me feel better because there was something in my head that had an order and a pattern and I just had to follow the instruction one after the other. (Haddon, 2003: 132)

The above quotation explains the details of the needs of Christopher's activities when he wants to meet his mother in London.

\section{Conclusion}

The Curious Incident of the Dog in the Night-Time is a novel about a boy named Christopher Boone who decides to be detective after finding his neighbor's dog dead. Characteristics of Asperger Syndrome are found in the novel and these symptoms are found in Christopher. Overall there are significant features of Asperger Syndrome possessed by Christopher: Lacking of Social Activity, Ability of Interpreting Object, and Ability to Set Routine Patterns. Today, Asperger's syndrome is technically no longer a diagnosis on its own. It is now part of a broader category called autism spectrum disorder (ASD). This group of related mental health issues shares some symptoms. Even so, lots of people still use the term Asperger's.

What distinguishes Asperger's Disorder from classic autism is its less severe symptoms and the absence of language delays. Children with Asperger's Disorder may be only mildly affected, and they frequently have good language and cognitive skills. To the untrained observer, a child with Asperger's Disorder may just seem like a neurotypical child behaving differently. Children with autism are frequently viewed as aloof and uninterested in others. This is not the case with Asperger's Disorder. Individuals with Asperger's Disorder usually want to fit in and have interaction with others, but often they do not know how to do it. They may be socially 
awkward, not understand conventional social rules or show a lack of empathy. They may have limited eye contact, seem unengaged in a conversation and not understand the use of gestures or sarcasm.

\section{References}

Attwood, T. (1998). Asperger's syndrome: A guide for parents and professionals. Philadelphia, PA: Jessica Kingsley Publishers.

Azwandi. (2005). Mengenal dan Membantu Penyandang Autisme. Jakarta: Departemen Pendidikan Nasional. Retrieved from https://meenta.net/6-pengertian-autismenurut-para-ahli/ on 23 May 2019.

Frith, U. (1991). Autism and Asperger Syndrome. New York, NY: Cambridge University Press. Gately, S. (2008). Facilitating reading comprehension for students on the autism spectrum. Teaching Exceptional Children, 40, 40-45. Retrieved January 31, 2009, from Education Research Complete database.

Haddon, Mark. (2003). The Curious Incident of the Dog in the Night-Time. London: Jonathan Cape, ltd.

Hallahan, D.P. and Kauffman, J. M. (2009). Exceptional Learners: An Introduction to Special Education. USA: Pearson Education, Inc. Retrieved from https://meenta.net/6-pengertian-autis-menurut-para-ahli/ on 23 May 2019.

Haryanto. (2011). Asesmen WPendidikan Luar Biasa. Yogyakarta: Fakultas Ilmu Pendidikan Universitas Negeri Yogyakarta. Retrieved from https://meenta.net/6pengertian-autis-menurut-para-ahli/ on 23 May 2019.

Hidayati. (2019). Anguish in Alexander Dumas' Novel "The Count of Monte Cristo". Language Literacy: Journal of Linguistics, Literature and Language Teaching. Retrieved from https://jurnal.uisu.ac.id/index.php/languageliteracy/article/view/1994/pdf_1 on 28 August 2019.

Ismawati, Esti. (2012). Metode Penelitian: Pendidikan Bahasa dan Sastra. Yogyakarta: Penerbik Ombak.

Kirby, Barbara L. What is Asperger syndrome? Online Asperger syndrome information and support. Retrieved from http://www.udel.edu/bkirby/asperger/aswhatisit.html on 28 May 2019.

Nugraheni, S. A. (2008). Efektivitas Diet Bebas Gluten Bebas Casein terhadap Perubahan Perilaku Anak Autis. Semarang: Pustaka Rizki Putra

Siegel, Bryna. Helping children with autism learn. New York: oxford university press. 2003.

Supartini, Endang. (2009). Program Son-Rise untuk Pengembangan Bahasa Anak Autis. Jurnal Pendidikan Khusus. Nomor 2, volume 5, 44-54. Retrieved from https://meenta.net/6-pengertian-autis-menurut-para-ahli/ on 23 May 2019.

Yuwono, Joko. (2012). Memahami Anak Autistik :Kajian Teoritik dan Empirik. Bandung: Alfabeta. Retrieved from https://meenta.net/6-pengertian-autismenurut-para-ahli/ on 23 May 2019. 